\title{
DONALD STEPHENS DAN PERANANNYA DALAM PEMBENTUKAN MALAYSIA
}

\author{
Saimin Ginsari \\ Joseph M. Fernando
}

\begin{abstract}
This article examines the role played by Donald Stephens, the President of the United National Kadazan Organisation (UNKO) and the owner of the Sabah Times newspaper in the formation of the Federation of Malaysia in 1963. His role has not been sufficiently examined in the existing literature. The article discusses the difficulties faced by Donald Stephens and UNKO in the effort to influence the Dusun and Murut communities in the interior of Sabah to accept the formation of Malaysia. Both the communities initially disagreed with the action of UNKO. But despite some initial hesitance, they eventually supported the formation of Malaysia. Donald initially opposed the proposed formation of Malaysia. But he then changed his mind during the first conference of the Commonwealth Parliamentary Association in Singapore on 21st July 1961 and recommended the establishment of the Malaysia Solidarity Consultative Committee (MSCC) to consider in depth the concept of Malaysia that was being proposed. This article also examines Donald Stephens' role in the formal negotiations of the formation of Malaysia, including the inter-government committee meetings and the declaration of Malaysia after the investigations conducted by the United Nations in North Borneo and Sarawak.
\end{abstract}

\section{Pengenalan}

Peranan pemimpin tempatan di wilayah Borneo khususnya pemimpin pro-Malaysia dalam merealisasikan penubuhan Malaysia merupakan antara aspek yang penting dalam sejarah pembentukan Malaysia. 
Pemimpin ini bukan sahaja membantu mempercepatkan penubuhan Greater Malaysia yang dicadangkan oleh Tunku Abdul Rahman, tetapi juga bertanggungjawab mempengaruhi berberapa ciri persekutuan Malaysia, termasuk kandungan perlembagaan persekutuan. Negerinegeri di Borneo mempunyai beberapa peruntukan tambahan dalam perlembagaan yang telah dirundingkan dalam mesyuarat Inter Governmental Committee (IGC). Tambahan Peruntukan perlembagaan kepada negeri-negeri di Borneo menjadikan Malaysia menjadi sebuah persekutuan bersifat asymmetric, kerana negeri-negeri dalam persekutuan Malaysia tidak lagi mempunyai peruntukan perlembagaan yang sama.

Donald Stephens, pemimpin utama masyarakat Kadazan merupakan pemimpin yang banyak mempengaruhi proses penyertaan Sabah dalam pembentukan Malaysia, selain Datu Mustapha Datu Harun pemimpin utama masyarakat Islam di Sabah. Stephens yang pada awalnya menentang rancangan Tunku telah menjadi individu penting yang terlibat dalam rundingan-rundingan penyertaan Sabah dalam persekutuan Malaysia. Stephens juga dilihat oleh British mempunyai kepimpinan yang lebih baik daripada pemimpin-pemimpin Sabah yang lain.

Bagaimanapun, penglibatannya dalam mesyuarat yang membabitkan perbincangan mengenai Malaysia lebih bersifat berhati-hati. Terdapat beberapa kemungkinan yang mempengaruhi sifat berhati-hati Stephens, antaranya pendirian penduduk di Borneo mengenai masa depan wilayah itu berbeza-beza. Sebahagian menyokong penuh penyertaan Sabah dalam pembentukan Malaysia, sebahagian pula lebih selesa merdeka dahulu sebelum memikirkan Malaysia, sementara sebahagian lagi menentang konsep Malaysia. Stephens dan masyarakat Kadazan dalam UNKO memilih untuk berada di tengah-tengah, menyokong Malaysia sambil meletakkan beberapa syarat-syarat tertentu.

\section{Reaksi Umum Pembentukan Malaysia di Borneo Utara (Sabah)}

Ketika rancangan Malaysia diperkenalkan, Gabenor Borneo Utara, William Goode menjelaskan ${ }^{1}$ respon secara keseluruhan di Borneo Utara adalah pelbagai. Walaupun ada yang menerima Malaysia dan berpandangan rancangan itu sesuai untuk masa depan Borneo Utara, tetapi mereka meminta pertimbangan-pertimbangan tertentu diambil kira. Masyarakat Cina umumnya mahukan Borneo Utara berkerajaan sendiri dahulu sebelum menyertai Malaysia. ${ }^{2}$ Masyarakat kaum asli pula takut dengan ancaman luar dan dalam, termasuk Indonesia dan 
anasir komunis. Masyarakat Islam pula menerima Malaysia untuk beberapa sebab peribadi, khususnya kerana agama. Masyarakat Islam Borneo Utara melihat Malaya sebagai negara Islam yang besar dan menjangkakan minoriti Islam di Borneo Utara akan mendominasi Borneo Utara selepas Malaysia. ${ }^{3}$ Ada juga yang berharap Malaysia akan membawa pembangunan di kawasan luar bandar. Tidak kurang juga yang menerima Malaysia kerana mereka diberitahu bahawa Malaysia adalah sesuatu yang baik untuk mereka. ${ }^{4}$

Goode juga memberitahu beberapa kumpulan yang menolak Malaysia disebabkan oleh ketakutan mereka terhadap penguasaan Melayu dan Islam di Borneo Utara pada masa akan datang. Goode membuat kesimpulan bahawa keadaan ini berlaku kerana pengalaman mereka dengan kerajaan Brunei dan Sulu 80 tahun yang lepas. ${ }^{5}$ Sesetengah kumpulan yang menolak Malaysia pula menyatakan rancangan Malaysia cuma perubahan pentadbiran daripada koloni British kepada Kuala Lumpur. ${ }^{6}$ Selebihnya, secara umum berpandangan penggabungan dengan wilayah-wilayah Borneo lebih menarik. Bagaimanapun ada yang menentang penggabungan dengan Sarawak kerana risau dengan aktiviti komunis di wilayah tersebut. ${ }^{7}$

Ketika laporan Cobbold diterbitkan, hasil laporan menyatakan kaum asli di Borneo Utara masih menimbulkan keraguan terhadap Malaysia dan meminta perlindungan termasuk perlantikan ketua negeri daripada kaum asli, imigresen ke Borneo Utara dibawah kawalan kerajaan negeri, pengekalan bahasa Inggeris sebagai bahasa rasmi dan medium pertuturan dan kedudukan istimewa kaum asli. ${ }^{8}$ Masyarakat Cina pula umumnya mahukan Borneo Utara berkerajaan sendiri dahulu dan jika persekutuan Malaysia diteruskan, mereka mahu persekutuan tersebut longgar dengan kuasa persekutuan terhad dalam hubungan luar, pertahanan dan keselamatan dalaman. ${ }^{9}$

Demokratic Party, sebuah parti berasaskan sokongan kaum Cina mengambil pendirian untuk berkerajaan sendiri terlebih dahulu sebelum memikirkan Malaysia. United Party, Liberal Party dan sebuah parti yang didominasi oleh masyarakat Dusun dan Murut iaitu United Pasok Momogun Party (UPMP) dibawah G.S. Sundang pula mengambil pendirian yang sama, iaitu menolak Malaysia. ${ }^{10}$ United Sabah National Organisation (USNO) sebuah parti yang didominasi oleh masyarakat Islam, menyokong penuh Malaysia khususnya sebab pertahanan (daripada ancaman komunis). USNO juga menyokong penuh bahasa Melayu sebagai bahasa kebangsaan dan berpandangan bahawa agama rasmi negeri sepatutnya Islam. USNO juga mahu lebih banyak sekolah agama dibina di Borneo Utara. ${ }^{11}$ Sebuah lagi parti berasaskan kaum asli masyarakat Kadazan, United National Kadazan Organisation (UNKO) menyokong pembentukan Malaysia tetapi dengan beberapa 
syarat. ${ }^{12}$ Antara syarat tersebut termasuk tiada agama rasmi di Borneo Utara, bahasa Inggeris menjadi bahasa rasmi tanpa ada had masa dan bahasa Kadazan akan menjadi bahasa penghantar di sekolah-sekolah kawasan Kadazan, hak istimewa yang sama seperti kaum asli kepada anak kahwin campur, imigresen di bawah kerajaan negeri, perwakilan ke parlimen lebih banyak berbanding negeri-negeri lain dan pegawaipegawai British kekal di Borneo Utara selepas Malaysia sehingga anak tempatan mampu mengganti mereka. ${ }^{13}$

Ringkasnya, laporan Cobbold merumuskan dua parti yang diasaskan oleh pemimpin kaum asli, USNO dan UNKO menyokong pembentukan Malaysia. Pemimpin USNO, Datu Mustapha dan UNKO, Donald Stephens juga mendakwa majoriti penduduk kaum asli menerima dan mengalu-alukan Malaysia. Bagaimanapun, USNO (walaupun mendakwa mempunyai lebih 60 ribu ahli tetapi suruhanjaya Cobbold menganggarkan hanya seramai 21 ribu) dan UNKO dianggarkan mempunyai ahli seramai 20 ribu, dinafikan oleh UPMP bahawa masyarakat kaum asli di Borneo Utara menerima dan mengalu-alukan Malaysia. ${ }^{14}$ UPMP mempunyai ahli seramai 10,600. ${ }^{15}$

Pendirian Donald Stephens dan UNKO dalam laporan Cobbold memang sedikit mengejutkan kerana beliau pada mulanya berusaha keras merealisasikan persekutuan Borneo. ${ }^{16}$ Beliau juga menentang keras pembentukan Malaysia selepas Tunku membuat lawatan ke Brunei dan Sarawak. Donald Stephens mengubah pendiriannya beberapa minggu selepas bersama-sama Ong Kee Hui dari Sarawak dan A.M. Azahari dari Brunei menubuhkan United Front, pertubuhan yang diwujudkan untuk menentang rancangan Tunku. ${ }^{17}$ Bagaimanapun, selepas Laporan Cobbold diterbitkan, Donald Stephens menjadi antara orang penting bagi Borneo Utara dalam rundingan-rundingan pembentukan Malaysia, khususnya semasa mesyuarat Inter-governmental Committee (IGC) dan perjanjian Malaysia di London pada 9 Julai 1963 sehinggalah pengisytiharan Malaysia pada 16 September 1963.

\section{Donald Stephens dan Penubuhan United National Kadazan Organisation (UNKO)}

Donald Stephens merupakan ahli majlis perundangan dan eksekutif Borneo Utara dan mempunyai akhbar penerbitannya sendiri iaitu Sabah Times dan North Borneo News. Bagi kerajaan British, Donald Stephens diyakini lebih baik daripada Datu Mustapha Datu Harun, seorang pemimpin Suluk yang kemudiannya menubuhkan United National Sabah Organisation (USNO) pada bulan Disember 1961. Datu Mustapha Datu Harun digambarkan oleh British sebagai 'Very limited potentialities. Dislikes D.A. Stephens, who is both more competent and more forceful. '18 
Donald Stephens menubuhkan parti lebih awal dari pemimpinpemimpin lain pada bulan Ogos 1961 dinamakan United National Kadazan Organisation (UNKO). Penubuhan UNKO disifatkan oleh pemimpin-pemimpinnya sebagai reaksi terhadap rancangan pembentukan Malaysia. ${ }^{19}$ UNKO mahu melindungi masyarakat Kadazan dari aspek politik, ekonomi dan perkembangan sosial, pendidikan dan warisan kaum asli selepas pembentukan Malaysia. ${ }^{20}$ UNKO juga menyokong dasar British agar Borneo Utara mencapai taraf berkerajaan sendiri. ${ }^{21}$ UNKO mempunyai 60 buah cawangan dan kebanyakkannya di Pantai Barat dan residen pedalaman. Cawangan yang paling banyak ditubuhkan adalah di Penampang (9 cawangan) dan Papar (8 cawangan). ${ }^{22}$

Bagaimanapun, beberapa keputusan konvensyen UNKO yang diadakan pada 5 hingga 7 Ogos 1961, tidak dipersetujui oleh kumpulan masyarakat yang mendokong UNKO sendiri, iaitu masyarakat Dusun dan Murut. Dalam konvensyen tersebut, UNKO telah membuat keputusan menggunakan perkataan 'Kadazan' bagi merangkumi kaum Dusun dan Murut. Dua puluh ahli UNKO telah mengundi usul tersebut, sementara 4 orang tidak hadir. ${ }^{23}$ Isu ini akhirnya menjadi faktor perpecahan kepada UNKO dan masyarakat Dusun apabila sebilangan ahli UNKO keluar daripada parti dan menubuhkan United National Pasok Momogun Party (UNPMP). Selain itu, pendirian UNKO terhadap rancangan Malaysia juga dipercayai menjadi antara sebab beberapa pemimpin masyarakat Dusun tidak menerima UNKO. ${ }^{24}$

Bermula peristiwa ini, UNKO dan sebuah lagi parti yang ditubuhkan kerana tidak berpuas hati dengan konvensyen UNKO, iaitu United National Pasok Momogun Party (UNPMP) saling bersaing mempengaruhi masyarakat Dusun, Murut, Kadazan dan Rungus untuk memberi penjelasan terhadap rancangan Malaysia. UNKO menyokong pembentukan Malaysia sementara UNPMP menentang Malaysia. ${ }^{25}$ Bagaimanapun persaingan ini berakhir apabila G.S. Sundang presiden UNPMP (kemudiannya diubah kepada United Pasok Momogun Party UPMP) tidak lagi menentang Malaysia dan menarik balik petisyen yang dihantarnya ke Pertubuhan Bangsa-bangsa Bersatu pada 27 Oktober 1962. ${ }^{26}$ Pada 12 April 1964, UNKO dan UPMP membuat pertemuan di Tenom, Sabah bagi membuat rundingan menggabungkan UNKO dan UPMP dalam satu parti yang dinamakan United Pasok Momogun Kadazan Organisation (UPKO). ${ }^{27}$ Sepanjang tempoh ini juga, iaitu antara bulan Ogos 1961 hinggalah pengisytiharan Malaysia, UNKO menghadapi persaingan dengan USNO khususnya soal pengisian beberapa wakil dalam Majlis Perundangan, majlis eksekutif, perwakilan ke parlimen dan jawatan kabinet negeri. 


\section{Reaksi terhadap Cadangan Pembentukan Malaysia}

Secara ringkasnya, idea penyatuan wilayah tanah jajahan British sebenarnya sudah dicadangkan oleh Lord Brassey, Pengarah British North Borneo Chartered Company (NBCC) pada tahun 1887. ${ }^{28}$ Sir Cecil Clement, Gabenor Malaya dan negeri-negeri Selat dan Sir Malcom Macdonald ${ }^{29}$ Pesuruhjaya Tinggi British di Asia Tenggara juga mencadangkan satu konsep penggabungan yang hampir sama pada tahun 1949 di Singapura. ${ }^{30}$ Pada tahun 1957, muncul cadangancadangan dari pegawai-pegawai British untuk membentuk Persekutuan Borneo. Bagaimanapun, idea tersebut tidak menjadi kenyataan kerana keengganan Sultan Brunei, Sultan Omar Ali Saifuddin untuk menyertai persekutuan tersebut. ${ }^{31}$

Situasi di Borneo menyebabkan British mengadakan satu mesyuarat di Phoenix Park, Singapura pada 23 Januari 1960. Mesyuarat ini dipengerusikan oleh Sir Dennis Allen, Timbalan Pesuruhjaya Jeneral British di Asia Tenggara. ${ }^{32}$ Antara isu yang dikemukakan dalam mesyuarat ini adalah rancangan masa depan koloni British di wilayah Borneo. Mesyuarat ini turut mengemukakan perhatian bahawa kaum asli di wilayah Borneo tidak mengalu-alukan sebarang pemindahan pentadbiran daripada koloni British yang dianggap sebagai pelindung kepada orang Melayu atau Cina, yang secara tradisinya mereka takuti. ${ }^{33}$

Mesyuarat di Singapura kemudian disusuli dengan mesyuarat pada 29 Mac 1960 yang dipengerusikan oleh Sir John Martin..$^{34}$ Antara isu yang dibincangkan adalah berkenaan cadangan masa depan wilayah-wilayah jajahan British termasuk membentuk persekutuan yang lebih besar, merangkumi persekutuan Malaya, Singapura dan wilayah-wilayah Borneo. Timbul juga cadangan untuk merapatkan ketiga-tiga wilayah Borneo dan kemudiannya menggabungkan dengan Persekutuan Malaya dan Singapura dalam bentuk 'wider federation' ${ }^{35}$ Tetapi keengganan Brunei menyertai cadangan pegawai British membentuk persekutuan Borneo menyebabkan usaha merapatkan Borneo Utara dan Sarawak pula dilakukan. Bagaimanapun, mesyuarat melihat terdapat risiko penggabungan Borneo Utara dan Sarawak dibuat dengan tergesa-gesa kerana ada kemungkinan Sultan Brunei akan membuat hubungan rapat dengan Persekutuan Malaya. ${ }^{36}$ Usaha merapatkan Borneo Utara dan Sarawak bagaimanapun diteruskan dengan menggabungkan jabatan di kedua-dua wilayah koloni British itu. Ini termasuk Jabatan perkhidmatan meterologi, Jabatan kajian geologi dan badan kehakiman. Persidangan Borneo Inter-territorial yang bermesyuarat dua kali setahun sama ada di Kuching atau Jesselton juga ditubuhkan. Sebuah kawasan perdagangan bebas di Borneo juga ditubuhkan pada 26 Januari 1962. Selain itu, seorang pegawai British dilantik bagi menyelaras program merapatkan Borneo Utara dan Sarawak. ${ }^{37}$ 
Walau bagaimanapun, dalam tempoh dua minggu sebelum British membuat pengumuman untuk merapatkan wilayah-wilayah Borneo, Tunku secara tiba-tiba mempromosikan rancangan Malaysia. ${ }^{38}$ Tunku kemudiannya telah menyuarakan hasrat tersebut kepada Setiausaha Tanah jajahan British, Lord Home pada 3 Jun 1960 ketika menghadiri Persidangan Negara-negara Komenwal di London. ${ }^{39}$ Tunku juga menyuarakan hasrat yang sama kepada Menteri Hal Ehwal Tanah Jajahan Britain, Lord Perth. ${ }^{40}$ Selepas pertemuan tersebut, kerajaan British meminta pegawai-pegawai British di Pejabat Tanah jajahan untuk meneliti rancangan Tunku. Lord Selkirk, Pesuruhjaya Jeneral British di Asia Tenggara bagaimanapun berpandangan Tunku akan berhadapan dengan kesukaran untuk mendapat persetujuan daripada wilayah-wilayah Borneo kerana tahap ekonomi di wilayah-wilayah yang terbabit masih jauh. Wilayah-wilayah Borneo juga perlu lebih banyak perlindungan termasuk pertahanan dan keselamatan. ${ }^{41}$

Pejabat Tanah Jajahan di Asia Tenggara kemudiannya membincangkan rancangan Tunku dalam Borneo-Inter Territorial Conference dan Joint Defence Advisory di Kuching pada 25 Oktober 1960. ${ }^{42}$ Mesyuarat di Kuching tersebut umumnya bersetuju Malaysia merupakan satu penyelesaian jangka panjang untuk masa depan wilayah-wilayah Borneo. ${ }^{43}$ Gabenor Borneo Utara, Sir William Goode bagaimanapun berpandangan bahawa penduduk Borneo Utara belum bersedia untuk membuat keputusan yang besar. ${ }^{44}$ Bagaimanapun Tunku, tanpa terlebih dahulu merujuk kepada kerajaan British, telah membuat pengumuman cadangan pembentukan Malaysia ketika makan tengahari dalam Mesyuarat Kelab Penulis-penulis Luar di Singapura pada 27 Mei 1961. ${ }^{45}$ Selepas pengumuman tersebut, pelbagai reaksi disuarakan oleh pelbagai pihak. Reaksi pemimpin-pemimpin tempatan di wilayah Borneo pada peringkat awal tidak kedengaran. Ini kerana mereka tidak begitu mengetahui konsep sebenar rancangan Tunku pada peringkat awal. Lagipun, pada masa itu rancangan penggabungan Borneo Utara dan Sarawak sedang dalam perbincangan pihak British. ${ }^{46}$

Reaksi pemimpin-pemimpin tempatan di wilayah Borneo berubah selepas lawatan Tunku ke Brunei pada bulan Julai 1961. Kenyataan A.M. Azahari bahawa Tunku ${ }^{47}$ akan menjadikan Brunei, Sarawak dan Borneo Utara sebagai negeri-negeri baru dalam persekutuan Malaya dan menjadi negeri kedua belas, ketiga belas dan keempat belas menimbulkan kemarahan pemimpin-pemimpin di wilayah Borneo. ${ }^{48}$ Bagi A.M. Azahari, Brunei mahukan kemerdekaan terlebih dahulu sebelum menimbangkan rancangan Tunku. ${ }^{49}$ Donald Stephens juga diberitahu bahawa rakyat Brunei secara terbuka mengatakan rancangan Tunku adalah untuk menjajah Brunei dan wilayah-wilayah Borneo lain, dan percaya perletakan jawatan pegawai-pegawai Malaya di Brunei 
telah mendorong Tunku mengancam Brunei untuk menjadikannya negeri kedua belas. ${ }^{50}$ Bermula dari peristiwa ini, pemimpin-pemimpin tempatan Borneo mula percaya British telah memberikan wilayah Borneo termasuk Borneo Utara kepada Malaya. ${ }^{51}$ Masyarakat Cina pula telah memanggil mesyuarat untuk menubuhkan Borneo Chinese Association sebagai kebimbangan terhadap masa depan kaum mereka. ${ }^{52}$

Donald Stephens, pemilik suratkhabar dan menerajui Persatuan Kadazan Borneo Utara ${ }^{53}$ telah menyatakan pendiriannya terhadap rancangan Tunku dalam surat terbukanya kepada Tunku melalui suratkhabar miliknya, North Borneo News pada 7 Julai 1961. Beliau menyatakan bahawa jika Malaya membawa Borneo Utara membentuk Malaysia pada hari Malaya merdeka, kemungkinan besar Borneo Utara akan menyertai Malaysia. ${ }^{54}$ Tetapi Malaya sudah merdeka sedangkan Borneo Utara masih bergelut untuk mendapatkan kemerdekaan. Sementara itu, cadangan Malaya yang mahu wilayah-wilayah Borneo menyertai mereka sebagai negeri kedua belas, ketiga belas dan keempat belas dilihat oleh Stephens sebagai satu bentuk penjajahan oleh Malaya. Oleh yang demikian, Stephens berpandangan bahawa menyertai Malaya pada masa Borneo Utara masih dalam jajahan British, kelihatannya hanya satu pemindahan kawalan daripada British kepada Malaya. ${ }^{55}$

Donald Stephens juga menyatakan bahawa persekutuan Borneo adalah rancangan yang sedang diusahakan dan belum masanya untuk membuat pertimbangan penggabungan dengan Malaya. ${ }^{56}$ Beliau juga percaya apa sahaja cadangan dari luar Borneo termasuk rancangan Tunku adalah mencurigakan dan berkeinginan untuk memperluas kuasa. Walau bagaimanapun, Tunku menafikan rancangan Malaysia bertujuan untuk meluaskan kuasa atau menjajah wilayah-wilayah Borneo. ${ }^{57}$

Ringkasnya, Donald Stephens berpendirian bahawa perkara penting yang perlu dibuat terlebih dahulu adalah penyatuan tiga wilayah Borneo serta merdeka dahulu sebelum memikirkan penggabungan dengan Malaya untuk membentuk Malaysia. ${ }^{58}$ Donald Stephens juga yakin bahawa Sabah dan wilayah Borneo yang lain digunakan untuk memudahkan penggabungan Malaya dan Singapura. Ringkasnya, Tunku menggunakan rakyat Borneo untuk menyelesaikan masalahnya dengan Singapura. ${ }^{59}$ Bagaimanapun menurut Tunku, cadangan Stephens bahawa wilayah Borneo perlu merdeka terlebih dahulu sebelum menyertai pembentukan Malaysia adalah tidak masuk akal kerana sejak Malaya menjadi persekutuan, mana-mana wilayah boleh turut serta dalam persekutuan jika benar-benar berminat. ${ }^{60}$ Stephens bagaimanapun mengingatkan Tunku sekali lagi bahawa menyertai Malaya membentuk persekutuan Malaysia tanpa merdeka terlebih 
dahulu menggambarkan penjajahan masih berlaku. Ini sepertimana kenyataan Donald Stephens dalam suratkhabarnya:

We too have our pride, dear Tunku and even though we are only colonies - it is natural that we want to obtain our own independence. To join Malaya while we are still colonies can only mean one thing - that we would merely cease to be British colonies and become Malayan colonies instead. We can still be won over by friendship, understanding and patience, but any show of coercion, of forcing the issue will only produce the very opposite thing to what you have in mind. ${ }^{6}$

Pendirian Donald Stephens ini kemudiannya disusuli dengan penyertaannya dalam United Front (Barisan Bersatu), satu pertubuhan wilayah Borneo yang diwujudkan untuk menentang pembentukan Malaysia. United Front diwakili oleh Ong Kee Hui (Sarawak), Donald Stephens (Borneo Utara) dan A.M. Azahari (Brunei). ${ }^{62}$ Pada 10 Julai 1961, ketiga-tiga pemimpin ini kemudiannya telah bertemu di Jesselton, Borneo Utara dan sependapat bahawa rancangan Tunku tidak boleh diterima. ${ }^{63}$ United Front menyatakan bahawa tindakan Tunku adalah tergesa-gesa dan berharap ketegangan yang diwujudkan oleh Tunku akan dapat diperbaiki. ${ }^{64}$ United Front juga mengingatkan kerajaan British bahawa harapan rakyat di tiga wilayah Borneo perlu dipastikan terlebih dahulu kerana rancangan yang diberitahu oleh Tunku di Brunei dan Sarawak akan ditolak sepenuhnya oleh penduduk di tiga wilayah tersebut. Dalam kenyataan keras terhadap kerajaan British, pendirian ketiga-tiga wakil tersebut disuarakan dalam kenyataan yang berbunyi:

British Government should be advised that so far as the wishes of the people in the three territories are ascertainable, any plan in accordance with the pronouncements made by Tunku Abdul Rahman in Brunei and Sarawak would be totally unacceptable to the people of the three territories. ${ }^{65}$

Satu kenyataan lain juga dikeluarkan beberapa hari kemudian dan kenyataan ini khas kepada Tunku dan persekutuan Malaya. Kenyataan tersebut berbunyi:

We are against joining Malaysia as individual states, and what the Borneo territories to get together, so that when we talk with Malaya, it will be as equals and not as vassals.... and if we join Malaya now, the people who will come and take most of the top jobs will be Malayan the new expatriates. ${ }^{66}$

Walau bagaimanapun, tidak lama kemudian, pada 21 Julai 1961, Stephens mengubah sedikit pendiriannya selepas bertemu dengan Lee Kuan Yew ketika menghadiri Persidangan Persatuan Parlimen 
Komanwel (Commonwealth Parlimentary Association) di Singapura. Lee Kuan Yew dilihat banyak mempengaruhi Donald Stephens untuk memikirkan kembali rancangan penggabungan yang dicadangkan oleh Tunku. Lee Kuan Yew memberitahu Donald Stephens bahawa kaum asli di Borneo akan menjadi pengimbang kuasa dalam Malaysia. ${ }^{67}$ Maksud Lee Kuan Yew, kaum asli di Borneo akan menjadi pengimbang kuasa antara kaum Cina dengan kaum Melayu dan boleh menentukan dominasi politik di Malaysia sekiranya penggabungan Singapura, persekutuan Malaya dan wilayah Borneo berlaku. ${ }^{68}$

Donald Stephens pula menyatakan kepada Lee Kuan Yew bahawa rakyat Borneo tidak menolak cadangan Tunku sepenuhnya tetapi memerlukan masa untuk menyelidiknya. Sebagai balasan terhadap kesediaan Donald Stephens menimbangkan semula rancangan tersebut, Lee Kuan Yew menawarkan rakyat Borneo Utara 10 tajaan biasiswa untuk pelajar Borneo Utara belajar di mana-mana Universiti di Singapura. ${ }^{69}$ Satu lagi hasil penting pertemuan Donald Stephens dan pemimpin-pemimpin Singapura dan persekutuan Malaya di persidangan ini adalah penubuhan Malaysia Solidarity Consultative Committee (MSCC), pada 23 Julai 1961 yang dicadangkan oleh Donald Stephens sendiri bersama Yeo Cheng Hoe dari Sarawak. ${ }^{70}$ MSCC ditubuhkan sebagai satu cara untuk pemimpin-pemimpin Borneo mengetahui dengan lebih mendalam rancangan Malaysia oleh Tunku. ${ }^{71}$

Selepas persidangan di Singapura, Tunku pula telah mempelawa Donald Stephens berbincang dan melihat sendiri pembangunan yang berlaku di Malaya sejak merdeka. Dalam dua jam pertemuan dengan Tunku, kebimbangan Donald Stephens terhadap kemungkinan berlaku penjajahan Malaya sedikit hilang. ${ }^{72}$ Beliau bagaimanapun masih menyuarakan kerisauannya sekiranya orang Malaya datang ke Borneo dan akan memonopoli pekerjaan di Borneo Utara serta menjawat jawatan tinggi di Borneo Utara selepas penubuhan Malaysia. ${ }^{73}$

Sungguhpun Donald Stephens mula mengubah pandangannya terhadap Malaysia, beliau bagaimanapun masih berharap supaya Borneo Utara merdeka terlebih dahulu sebelum menyertai pembentukan Malaysia. Donald Stephens tidak meragui keikhlasan Malaya tetapi yang menakutkan adalah status Borneo Utara sebagai sebuah tanah jajahan British akan secara automatik menjadi jajahan Malaya. Oleh yang demikian, Donald Stephens menyatakan bahawa Borneo Utara harus berkerajaan sendiri sebelum rakyat Borneo Utara boleh membuat keputusan sama ada mahu menjadi rakan kongsi dalam Malaysia. Ringkasnya, menurut beliau, berkerajaan sendiri adalah pra-syarat bagi keputusan penyelesaian mengenai persoalan Malaysia. ${ }^{74}$

Pertemuan pemimpin-pemimpin Borneo Utara dengan pemimpin Singapura dan persekutuan Malaya sepanjang bulan Julai dan 
Ogos 1961, telah menghilangkan keraguan dan ketakutan mereka terhadap rancangan Tunku. ${ }^{75}$ Beliau juga menjelaskan bahawa Tunku tidak sepenuhnya mendesak pemimpin-pemimpin Borneo untuk terlibat dalam rancangan tersebut dan hanya menjelaskan manfaat pembentukan tersebut kepada mereka. Oleh yang demikian, pada pandangan pemimpin-pemimpin yang membuat lawatan ke Singapura dan Malaya, menyertai Malaysia adalah perkara yang memberi manfaat untuk masa depan dan menawarkan Borneo Utara perlindungan yang lebih baik daripada ancaman luar. ${ }^{76}$ Donald Stephens juga telah memberi jaminan bahawa tidak akan berlaku campurtangan atau penjajahan daripada Malaya di Borneo sekiranya menyertai Malaysia. Ringkasnya, Donald Stephens yakin rancangan Malaysia adalah bermanfaat dan perlu direalisasikan. ${ }^{77}$

Beberapa bulan selepas pertemuannya dengan pemimpin Malaya dan Singapura, Donald Stephens kelihatan serius untuk menyertai Malaysia dan ini dilihat dalam kenyataannya akhbar miliknya, North Borneo News pada 18 September 1961:

You may known that the government of Singapore, a self-governing country, will soon be modifying its existing constitution before 1963. We believe that the Federation government will take similar steps in order to become a member-country or to be one of the partners of greater Malaysia scheme. To do this the Malayan government will have to call for a meeting of all its rulling ministers and it will be expected that not more than twothirds of those who are elected to take part in the drafting of the constitution or take part in the drafting of the constitution or Malaysia scheme. We on our part, have to be absolutely certain that in the event of our eventual becoming a member of the scheme we will not lose in any way or manner. ${ }^{78}$

Kenyataan Donald Stephens ini menggambarkan bahawa secara prinsipnya beliau menerima Malaysia tetapi menghadapi kesukaran untuk menyakinkan rakyat Borneo Utara bahawa ketakutan mereka terhadap beberapa perkara seperti penguasaan penduduk Singapura dan Malaya ke Borneo Utara dapat diselesaikan. Beliau juga memikirkan bagaimana jaminan untuk melindungi perkara-perkara yang ditakuti dapat dirundingkan. Oleh yang demikian ketika menjelaskan kepada rakyat Borneo Utara terhadap kemungkinan tiada kebebasan agama dan kedatangan kaum Cina dan kaum lain dari Singapura dan Malaya untuk mengisi jawatan-jawatan di Borneo Utara, Donald Stephens mengatakan:

Some people have said that joining the Malaysia will mean the discontinuance of the freedom of worships to God and etc, that they will be prohibited from rearing domestic animals such as pigs and others, to the 
local are passed on to the Malayans, and that unemployed Chinese from Singapore or Malaya will all said for this country. I would like to say that all these are only mere imaginations and are not true at all for if they were really so, I will be the first one to oppose to the proposal. Contrary to all the imaginations or assumptions above, I personally had discovered during my visit or tour in the Federation that all forms of religious worships were allowed and similarly all kinds of animals could be reared including pigs etc. with no restrictions of any sort being imposed upon the people. Regarding the fears that the workless Chinese or other races from Singapore or Malaya who may likely immigrate to North Borneo, I would say that this will only happen on our prior approval. When we become one of the members of the Malaysia, we will only permit those qualified people to come in our country for we need their services. ${ }^{79}$

Kenyataan Donald Stephens ini menggambarkan beliau yakin perkaraperkara yang ditakuti oleh rakyat Borneo Utara akan dilindungi. Beliau juga memberi harapan bahawa prestasi Malaysia akan lebih baik daripada prestasi kerajaan British. Beliau mendakwa prestasi kerajaan British di Borneo Utara dalam pelbagai aspek tidak begitu baik. ${ }^{80}$ Menurutnya, selepas mentadbir Borneo Utara sekian lama, Borneo Utara tetap ketinggalan dan jauh ke belakang dalam pelbagai aspek. Oleh yang demikian, Borneo Utara perlu bantuan khususnya kewangan daripada kerajaan untuk membantu memperbaiki kedudukan yang ada dan memajukan pendidikan, ekonomi dan komersial sepertimana kaum lain. ${ }^{81}$

Mesyuarat Malaysia Solidarity Consultative Committee (MSCC) mengukuhkan pendirian Donald Stephens bahawa keputusan menyertai Malaysia adalah tepat walaupun beberapa kenyataannya dilihat masih ada keraguan terhadap Malaysia. Ketika mesyuarat pertama MSCC di Jesselton pada 24 Ogos 1961, Donald Stephens menyatakan bahawa ketika pertemuan pemimpin-pemimpin Borneo dan Malaya pada 10 Ogos 1961 di Kuala Lumpur, keresahan dan kekhuatiran mereka terhadap perkara-perkara yang ditakuti sekiranya menyertai Malaysia sedikit berkurangan. ${ }^{82}$ Dalam mesyuarat kedua MSCC di Dewan Perundangan Selangor pada 6 dan 7 Januari 1962, Donald Stephens sekali lagi melahirkan keyakinan bahawa apa yang dikhuatiri sebelum ini tidak akan berlaku. Dalam kenyataannya dalam mesyuarat tersebut, beliau menyatakan:

I have spoken of fears and misgivings, I my self and I stress, I personally have had many of these misgivings cleared or reduced, but I have always also stressed the need for us all to go into details so that as the knots are untangled the people of the countries concerned will be kept in better touch and will be in a better position to know when the times comes to make a decision whether they would want to see their respective countries become 
a partner in Malaysia. I have fought against sabah being bulldozed into Malaysia, and that stand remains. But I am quite sure now that no one wants to bulldoze anybody else into Malaysia, if all are agreed and plans can be worked out to the satifaction of all concerned, can be the partnership which would ensure our future stability and security. ${ }^{83}$

Kenyataan-kenyataan pro-Malaysia Donald Stephens bagaimanapun telah mendapat kecaman pelbagai pihak. Dalam konvensyen UNKO pada 5 hingga 7 Ogos, keputusan pendirian parti terhadap rancangan Malaysia dikecam oleh pemimpin-pemimpin kaum Asli. OKKSedomon, Ketua Kaum Asli telah memanggil mesyuarat Ketua-ketua kaum Asli Borneo Utara pada 4 September 1961 bagi menolak pendirian UNKO dan sebarang gerakan sokongan terhadap rancangan Malaysia. ${ }^{84}$ Donald Stephens juga didakwa menjual Borneo Utara berdasarkan kenyataan akhbarnya di Singapura, yang melaporkan bahawa pada tahun 1963, Borneo Utara akan terikat dalam Malaysia. ${ }^{85}$ Donald Stephens bagaimanapun menafikannya dan menyatakan bahawa beliau tidak pernah terfikir untuk menjual Borneo Utara sepertimana sangkaan ramai. Beliau tegas mengambil pendirian bahawa apa yang perlu dibuat terlebih dahulu adalah berkerajaan sendiri sebelum memikirkan persoalan sama ada mahu menyertai Malaysia atau tidak. Donald Stephens juga ada diberitahu oleh seorang pegawai kanan British bahawa Pentadbiran Koloni British Borneo Utara akan meminta kerajaan British supaya tidak memaksa Borneo Utara menyertai Malaysia. ${ }^{86}$

Sungguhpun kenyataan Donald Stephens secara umumnya pro Malaysia, tetapi beberapa kenyataanya menunjukkan bahawa beliau sedar terdapat penentangan di Borneo Utara terhadap Malaysia. Beliau bagaimanapun meminta supaya semua yang menentang Malaysia memberikan pandangan kepada Suruhanjaya Cobbold. ${ }^{87}$ Dalam kenyataan akhbarnya sebelum Suruhanjaya Cobbold menjalankan kerja-kerjanya, Donald Stephens menyatakan:

Sitting back and saying 'I dont want Malaysia' is not going to do anybody any good; if we must say why and make it sound good. If we like Malaysia we must also say why we like Malaysia. If we have fears and doubts about Malaysia bring them out so that they can be cleared. The best way is to put opinion on paper after careful thought and preparation. This will make sure that whatever we have to say will have the change of being given its due weight when the members of the commission sit down to write their report and make their recommendations on any matter which is going to concern our whole future. ${ }^{88}$

Bagi Donald Stephens dan UNKO, pendirian rasmi terhadap Malaysia terkandung dalam Laporan Cobbold yang diterbitkan pada 1 Ogos 
1962. UNKO, parti yang diterajui oleh Donald Stephens menyokong pembentukan Malaysia kerana percaya masa depan Borneo Utara untuk mendapatkan kemerdekaan adalah dengan menyertai Malaysia. UNKO juga khuatir jika Borneo Utara berkerajaan sendiri dahulu, ini akan menyebabkan kaum Cina mendominasi pendidikan dan ekonomi. Risiko yang lebih besar adalah kemungkinan Borneo Utara didominasi oleh fahaman komunis. Kedua, UNKO berpandangan Malaysia adalah langkah keselamatan terbaik pada masa hadapan bagi wilayah-wilayah jajahan British di Asia Tenggara. Ini kerana gabungan wilayah-wilayah ini akan membentuk satu unit yang kuat dan memainkan peranan penting dalam pertahanan negara-negara komenwal. UNKO juga menyatakan bahawa hanya melalui Malaysia, ideologi komunis dihapuskan dan masalah ras di wilayah Borneo juga akan dapat diselesaikan. Ketiga, pemberian kedudukan istimewa kepada kaum Asli akan memberi mereka peluang untuk bersaing dengan kaum Cina. Keempat, UNKO berpandangan bahawa dengan Malaysia, masalah pembangunan luar bandar Borneo Utara akan diatasi. ${ }^{89}$

\section{Cabaran Merealisasikan Malaysia}

Pendirian rasmi UNKO dalam Laporan Cobbold menambah ketegangan dengan parti-parti yang menolak Malaysia termasuk UPMP dan United Party. G.S. Sundang presiden UPMP, mendakwa presiden UNKO dan USNO yang pro-Malaysia bukanlah kaum Asli di negara ini. Sundang mengatakan Donald Stephens merupakan seorang kacukan (Serani) dan Datu Mustapha adalah Suluk dari Filipina. ${ }^{90}$ Ketika menjawab dakwaan G.S. Sundang bahawa beliau adalah Serani, Donald Stephens menjelaskan bahawa Undang-undang Persatuan Kadazan Penampang dan dibawah perlembagaan UNKO, telah mengesahkan bahawa kaumnya adalah Kadazan kerana datuknya adalah Kadazan dan telah tinggal lama di sini. ${ }^{91}$ Bapanya, Jules Stephens mempunyai darah Kadazan dari keturunan Orang Tua (OT) Limbahau, di Papar manakala ibunya, Edith Margaret Mary Cope pula mempunyai darah Kadazan-Jepun. ${ }^{92}$

Selepas Laporan Cobbold diterbitkan, Donald Stephens bersama Datu Mustapha mempertingkatkan usaha memberi penjelasan kepada rakyat Borneo Utara mengenai Malaysia ketika lawatan masingmasing ke cawangan parti di seluruh pelusuk Borneo Utara. ${ }^{93}$ Donald Stephens juga menyifatkan pengolakan yang berlaku dalam kalangan pemimpin-pemimpin Borneo Utara berkaitan rancangan berkerajaan sendiri, kemerdekaan dan rancangan Malaysia perlu ditangani dengan baik. Menurut Donald Stephens, masyarakat perlu bersedia apabila tiba masa untuk berkerajaan sendiri dan mereka sebagai pemimpin 
juga akan bersedia memikul tanggungjawab yang diberikan. ${ }^{94}$ Donald Stephens juga mengingatkan rakyat supaya bersedia terhadap kemungkinan kehilangan hak-hak jika tidak bersatu dalam satu badan atau persatuan selepas menjadi sebahagian daripada Malaysia, sepertimana kenyataannya:

Also in order that we are capable of carrying out all required works when we become a member of the Malaysia we have to be keen and have the interest to work in close co-operation with others. If we are not alert and smart we will certainly lose our privileged rights, which after us will be passed on to our coming future generation. So it is one of the wisest ways that which will enable us to achieve the rights entitled to us, is to unite into a body or organization. ${ }^{95}$

Kenyataan Donald Stephens ini bagaimanapun tidak banyak mengubah ketakutan dan kebimbangan sebilangan masyarakat di Borneo Utara. G.S. Sundang, Peter Lo dan beberapa pemimpin UPMP dan United Party masih mempersoalkan beberapa perkara mengenai Malaysia ketika usul mengenai Malaysia dibentangkan di Majlis Undangan Borneo Utara pada 12September 1962. ${ }^{96}$ Majlis Undangan Borneo Utara mengalu-alukan keputusan secara prinsipnya penubuhkan Malaysia pada 31hb Ogos 1963 dengan 18 ahli menyokong. Majlis Undangan Borneo juga bersedia untuk menghantar beberapa ahli Majlis Undangan Borneo Utara mewakili Borneo Utara ke Mesyuarat Inter-Governmental Committee (IGC).${ }^{97}$ G.S. Sundang yang masih tidak menerima Malaysia telah meminta namanya dibuang dalam senarai wakil Borneo Utara ke mesyuarat IGC. ${ }^{98}$ Selain G.S. Sundang, R.N. Turner (Ketua Setiausaha Borneo Utara), W.K.H. Jones, (Peguam Borneo Utara), H.W. Davidson (Setiausaha Kewangan), Khoo Siak Chiew, Donald Stephens dan Datu Mustapha Datu Harun juga disenaraikan untuk mewakili Borneo Utara ke mesyuarat tersebut. ${ }^{99}$

Semasa perbincangan mengenai usul Malaysia di Majlis Undangan tersebut, Donald Stephens menyatakan bahawa Malaysia harus mengekalkan autonomi kerajaan Borneo Utara dan menjangkakan perkara pelajaran dan kewangan akan menjadi perkara kontroversi dalam mesyuarat IGC. ${ }^{100}$ Beliau mendakwa menerima jaminan daripada Malaya bahawa perkara agama di bawah bidang kuasa kerajaan negeri dan menyatakan bahawa tiada agama rasmi negeri kerana peruntukan dalam perlembagaan Malaya berkenaan agama tidak terpakai di Borneo Utara. ${ }^{101}$ G.S. Sundang yang masih menunjukkan rasa tidak senangnya terhadap status Borneo Utara yang disamakan dengan Pulau Pinang dan Melaka. Kenyataannya ini bagaimanapun menimbulkan kemarahan kepada Donald Stephens dan Datu Mustapha. ${ }^{102}$ G.S. Sundang menegaskan bahawa beliau hanya akan menerima Malaysia 
jika Malaysia adalah satu rancangan penggabungan negeri-negeri yang berkerajaan sendiri. Oleh itu menurutnya, jika Borneo Utara tidak mendapat hak negeri sepenuhnya, dia akan membuat rayuan di PBB. ${ }^{103}$ William Goode telah menasihati G.S.Sundang agar menarik balik petisyennya di PBB. ${ }^{104}$ Pada 27 Oktober 1962, G.S. Sundang telah menulis surat kepada Setiausaha Agung PBB untuk menarik petisyennya. Beliau memberitahu telah menerima Malaysia secara prinsipnya dan UPMP akan menyertai Perikatan Sabah. ${ }^{105}$

Pada 22 Oktober 1962, mesyuarat plenary pertama InterGovernmental Committee telah dibuat di Jesselton. Semasa mesyuarat tersebut Donald Stephens telah membangkitkan isu perbincangan dan perjanjian yang berlainan antara Borneo Utara, Sarawak, Singapura dan Brunei. ${ }^{106}$ Donald Stephens sedikit terkilan kerana hasil rundingan dan syarat-syarat penggabungan antara kerajaan Malaya dan Singapura tidak diumumkan. ${ }^{107}$ Dalam minit mesyuarat IGC pada 22 Oktober 1962 ketidakpuasan Donald Stephens dinyatakan:

\begin{abstract}
$\mathrm{Mr}$ Stephens explained that it would be very difficult for the political parties in North Borneo to commit themselves to any Agreements while they were unable to discover what terms were being agreed over Brunei's entry into Malaysia, or how the Malayan-Singapore Agreement of the $15^{\text {th }}$ November 1961 was to be implemented in detail. Pending the outcome of the Malayan Brunei talks it was necessary for North Borneo to reserve her final position on the matters that were under discussion. ${ }^{108}$
\end{abstract}

Oleh yang demikian, Donald Stephens meminta supaya hal yang sama tidak berlaku kepada rundingan Malaya dengan Brunei. Beliau meminta supaya apa-apa terma yang dipersetujui untuk Borneo Utara juga harus dijelaskan dan tertakluk kepada peruntukan yang diberi, bahawa mesti tidak kurang dan tidak lebih daripada apa yang dipersetujui untuk Brunei. ${ }^{109}$ Selepas mesyuarat pertama berakhir, pada 23 Oktober 1962 William Goode ada memberitahu Setiausaha Tanah Jajahan bahawa kerajaan koloni Borneo Utara telah mengemukakan beberapa kertas cadangan penting untuk dibincangkan dalam mesyuarat IGC berikutnya tetapi kertas cadangan itu disemak semula memandangkan pemimpin utama parti berkeras untuk memberi keutamaan kepada 20 perkara. ${ }^{110}$ William Goode juga memberitahu bahawa sikap perwakilan Malaya yang tidak membantu mengurangkan jurang antara 20 perkara dan perlembagaan persekutuan Malaya amat dikesali. ${ }^{111}$

Sehingga 20 Disember 1962, perwakilan IGC bersetuju dengan draf laporan dan tiada lagi mesyuarat selepas itu. Mereka juga bersetuju bahawa perkara-perkara terperinci akan dibincangkan dalam jawatankuasa kecil kerana banyak perkara perlu diperincikan. Antaranya adalah perubahan sistem daripada pentadbiran penuh 
Gabenor (di bawah pengawasan Ketua Jabatan Sekretariat dan profesional) kepada sistem kementerian dengan autoriti kepada menteri sementara menteri federal akan berpangkalan di Kuala Lumpur. ${ }^{112}$ Walaupun isi kandungan dokumen perlembagaan untuk persekutuan baru itu tidak diterangkan sepenuhnya kepada rombongan Borneo Utara, tetapi mereka merasa bahawa mereka dapat mendapatkan apa yang mereka mahukan melalui cadangan yang dikemukakan dalam 20 perkara. ${ }^{113}$ Malah Donald Stephens mengatakan selepas perbincangan IGC berakhir, masalah pembentukan Malaysia telah diselesaikan. Beliau juga begitu yakin perlembagaan Malaysia yang baru akan berdasarkan kepada laporan IGC. ${ }^{114}$

Pada 16 Disember 1962, pilihan raya Kerajaan Tempatan telah diadakan. Pilihan raya kerajaan tempatan yang diadakan pada 16 Disember 1962 menyaksikan daripada 137 kawasan, USNO menang 54 kawasan, UNKO (38), Borneo Utara National Party - BUNAP (29), UNPMP (12) dan Bebas (4). Selepas itu, Majlis Kebangsaan Perikatan Sabah telah membahagikan kerusi Majlis Undangan Borneo Utara kepada USNO (8), UNKO (5), BUNAP (4), UNPMP (1). Kerusi parlimen pula menyaksikan USNO mendapat 6 wakil, UNKO (5), BUNAP (4) dan UNPMP (1). Keempat-empat parti juga mempunyai seorang wakil dalam Dewan Negara. ${ }^{115}$ USNO, UNKO dan BUNAP masing-masing mempunyai dua Menteri, sementara UNPMP satu. ${ }^{116}$ Kemenangan besar UNKO dan USNO dalam pilihan raya Majlis tempatan ini menunjukkan rakyat Borneo memilih parti yang memperjuangkan kemerdekaan menerusi Malaysia.

Selepas pilihan raya Kerajaan Tempatan, Donald Stephens menghadapi satu lagi cabaran baru dalam politik. Donald Stephens diuar-uarkan akan menjadi Ketua Menteri dan Datu Mustapha sebagai Ketua Negeri (Yang di-Pertua Negara). Perkara ini dipersetujui bersama oleh kerajaan British dan kerajaan Malaya, tetapi beberapa pemimpin dan parti di Borneo Utara tidak menyenangi keadaan tersebut. Tun Razak sering memberi pandangan yang kurang baik terhadap kebolehan kepimpinan Datu Mustapha ${ }^{117}$ sebaliknya, beliau mempunyai pandangan yang berbeza terhadap Donald Stephens kerana pada pandangannya, Donald Stephens boleh mengawal keadaan di Borneo Utara berbanding pemimpin-pemimpin lain. ${ }^{118}$ Bagaimanapun, Tun Razak mengatakan gandingan mereka berdua akan berhasil kerana Stephens dan Mustapha berkawan baik. ${ }^{119}$ Sesetengah orang bagaimanapun tidak bersetuju dengan pandangan ini dan mendakwa ramai penduduk di Borneo Utara merasakan Datu Mustapha seorang yang berkarisma dan masyarakat Cina hormat kepadanya. Malahan ada laporan mengatakan bahawa bukan Donald Stephens yang membawa masyarakat Cina menghasilkan 20 perkara, tetapi Datu Mustapha. 
Datu Mustapha dipercayai tidak mahu menjadi Ketua Negeri Sabah yang pertama kecuali beliau diberikan kuasa yang banyak. Beliau juga dipercayai masih mahu bersaing untuk jawatan ketua menteri daripada Donald Stephens ${ }^{120}$ dan didakwa akan bergiat dalam politik sepertimana kenyataan dari pejabat koloni Borneo Utara:

Relation between members and their civil servants are good. Although the betting is still that Datu Mustapha will be Yang di-Pertua Negara and Donald Stephens Chief Minister, evidence is accumulating that Datu Mustapha will not be content to be a constitutional figurehead, but therefore either try to contest the chief ministership with Stephens or go to Kuala Lumpur. ${ }^{121}$

Donald Stephens juga bakal menghadapi kesukaran mendapat kerjasama daripada masyarakat dan parti Cina yang tidak senang dengan Donald Stephens khususnya isu kenyataan parti UNKO dan Stephens dalam laporan Cobbold. Antara kenyataan UNKO dalam laporan tersebut adalah: 'Self-government first would mean that the heirs, when the British leave, would be the Chinese owing to their educational and economic superiority. This in turn could lead to domination by Communism. ${ }^{122}$ Oleh yang demikian, ada dakwaan bahawa Borneo Utara National Party (BUNAP) satu parti gabungan Democratic Party dan United Party, akan menyokong USNO bagi menguasai Badan eksekutif dan Perundangan Borneo bagi memastikan Donald Stephens tidak akan kekal menjadi Ketua Menteri. ${ }^{123}$ Situasi inilah yang kemudiannya menjadi salah satu punca krisis politik di Sabah tidak sampai setahun selepas Malaysia dibentuk.

\section{Merealisasikan Penyertaan Sabah dalam Pembentukan Malaysia}

Laporan Inter Governmental Committee (IGC) telah diterima dan diluluskan sebulat suara oleh Majlis Undangan Borneo Utara pada 13 Mac 1963. ${ }^{124}$ Dalam mesyuarat tersebut, Donald Stephens yakin pilihan yang dibuat adalah betul dan meminta pihak luar berhenti membuat pandangan negatif terhadap usaha mereka. Menurutnya:

There are those in the outside world who know next to nothing about us who have tried to discredit our work as that of stooges of the British or the Malayans. These people should have been at the IGC meetings because they would have found a Sabah team fighting for what they believe to be Sabah's rights and being quite fearless in so doing. ${ }^{125}$

Beliau turut yakin bahawa Malaysia adalah apa yang dimahukan oleh rakyat Sabah (Borneo Utara) dan mereka memilih Malaysia bukan 
sebagai sekutu penjajah seperti mana dakwaan sesetengah pihak, tetapi dibuat selepas perbincangan beberapa lama dan berhati-hati. ${ }^{126}$ Pemimpin-pemimpin Borneo Utara juga yakin itu adalah kehendak mereka dan membuat kesimpulan bahawa tidak dapat dinafikan Malaysia adalah harapan mereka untuk mencapai kemerdekaan awal dan yakin Malaysia akan memastikan Borneo Utara kukuh dengan masa hadapan yang bahagia, makmur dan stabil. ${ }^{127}$

Perjanjian Malaysia ditandatangani pada 9 Julai 1963 dan 31 Ogos 1963 adalah tarikh pengisytiharan Malaysia sepertimana yang ditetapkan dalam kenyataan Bersama Tunku dan perdana Menteri Britain, Harold Macmillan pada 1 Ogos 1962. ${ }^{128}$ Indonesia dan Filipina bagaimanapun masih tidak menerima pembentukan Malaysia. Kedua-dua buah negara ini mendakwa Malaya mempunyai perjanjian pertahanan dengan British yang disebut sebagai 'neo-colonial plot', merujuk kepada keinginan membesarkan kawasan dan pengaruh mereka. ${ }^{129}$ Oleh yang demikian, pada 3 Julai 1963, Presiden Filipina, Macapagal menjemput Tunku dan Presiden Indonesia. Sukarno untuk bertemu di Manila bagi membincangkan secara diplomasi isu pembentukan Malaysia. Hasilnya, U Thant, Setiausaha Agung Bangsa-Bangsa Bersatu memutuskan untuk menghantar satu pasukan bagi mendapatkan pandangan rakyat di wilayah-wilayah Borneo terhadap Malaysia. ${ }^{130}$

Ketika memberi maklum balas terhadap keputusan PBB menghantar pasukan penyiasat ke wilayah-wilayah Borneo, Donald Stephens mengatakan bahawa jika ada referendum, cadangan tersebut mestilah daripada rakyat Borneo Utara sendiri dan bukan desakan daripada luar. ${ }^{131}$ Donald Stephens juga menjelaskan Parti Perikatan Sabah telah mengambil pendirian untuk tidak menerima referendum yang dijalankan sama ada oleh PBB mahupun mana-mana badan lain. Mereka juga akan mengumumkan kemerdekaan Borneo Utara pada 31 Ogos 1963 sama ada Malaysia dibentuk atau tidak pada tarikh tersebut. ${ }^{132}$ Beliau menjelaskan:

.....the die is cast. We must have our merdeka on August 31 $1^{\text {st }}$. If Malaysia is suggested at a later date, then we can look at it again when the time comes. Let us make it clear that what we want is firstly our independence and secondly Malaysia. If we cannot have independence and Malaysia at the same time, then let us have independence first and Malaysia later. ${ }^{133}$

Pada 8 Ogos 1963, Majlis Perundangan Borneo Utara sebulat suara bersetuju bahawa Borneo Utara akan merdeka pada 31 Ogos 1963. Tunku bagaimanapun tidak berpuas hati dengan keputusan Majlis Perundangan Borneo Utara tersebut. Ketika bercakap dengan pemberita sebelum bermesyuarat dengan pemimpin-pemimpin Borneo pada 16 
Ogos 1963, Tunku juga mempersoalkan bahawa tiada gunanya Malaysia jika Borneo Utara membentuk kerajaan sendiri. Dalam reaksi balas Donald Stephens, beliau menyatakan Tunku salah faham kerana Borneo Utara hanya bersetuju menerima pasukan PBB walaupun mereka dengan sekeras-kerasnya membantah PBB datang. Menurutnya, Borneo Utara mempunyai kerajaan sendiri dan tidak sepatutnya PBB datang. ${ }^{134}$

Pada 18 Ogos 1963, sekembalinya Donald Stephens dari Malaya, beliau telah membuat kenyataan agar semua parti politik di Malaysia bersatu untuk memastikan Malaysia direalisasikan. ${ }^{135}$ Beliau juga memberitahu bahawa kemerdekaan Borneo Utara pada 31hb Ogos 1963 adalah kehendak majoriti dan kemerdekaan ini sebagai sebahagian daripada Malaysia. ${ }^{136}$ Tunku yang ragu-ragu dengan kenyataan ini telah menggunakan kuasa parlimen Malaya untuk memastikan Borneo Utara dan Sarawak kekal menyertai pembentukan Malaysia. Parlimen Malaya telah meminda Seksyen 4 dalam Akta Malaya pada 20 Ogos 1963 yang terkandung dalam artikel 159, dengan memasukkan Sabah dan Sarawak sebagai sebahagian daripada Malaysia dari sudut perlembagaan. ${ }^{137}$

Pindaan Perlembagaan Persekutuan Malaya yang sepatutnya dibuat pada 31 Ogos 1963 sekiranya tarikh tersebut adalah pengisytiharan Malaysia, bagaimanapun tidak mengubah keputusan yang diputuskan dalam Majlis Perundangan Borneo Utara pada 8 Ogos 1963. Borneo Utara telah diberi kemerdekaan pada 31 Ogos 1963 oleh British. ${ }^{138}$ Sebagai persiapan terakhir sebelum kemerdekaan, William Goode telah menggantikan sistem ahli kepada sistem menteri penuh dengan barisan yang diketuai oleh Ketua Menteri dan enam orang Menteri. Donald Stephens dilantik sebagai Ketua menteri. Soal Pertahanan dan hubungan luar pula masih menjadi tanggungjawab British. ${ }^{139}$ Sir William Goode dikekalkan sebagai wakil Ratu sehingga Malaysia diisytiharkan. Upacara pengisytiharan kemerdekaan telah diadakan di Jesselton. Pada tarikh itu juga, Borneo Utara secara rasmi bertukar nama kepada Sabah dan diberikan hak berkerajaan sendiri. ${ }^{140}$ Dalam ucapan Gaboner terakhir Borneo Utara itu, beliau begitu yakin dengan Ketua Menteri, Donald Stephens akan membela dan menjaga rakyat Sabah. ${ }^{141}$

Bagaimanapun, dua hari sebelum Borneo Utara diberi kemerdekaan, perjanjian perubahan tarikh pengisytiharan Malaysia ditandatangani di Singapura pada 28 Ogos 1963. Donald Stephens menjadi wakil Borneo Utara dalam perjanjian tersebut. ${ }^{142}$ Pada 12 September 1963, Majlis Undangan Borneo Utara pula membuat keputusan untuk tetap menyertai persekutuan Malaysia walau apapun keputusan PBB. ${ }^{143}$ Pada 14 September 1963, laporan tinjauan PBB dikeluarkan dan hasil laporan menyatakan bahawa sedikit sahaja bukti tentangan bersuara terhadap Malaysia tetapi teratur di Borneo Utara. ${ }^{144}$ Situasi ini memudahkan proses pengisytiharan Malaysia yang disempurnakan Did you mean: 
approved by $u n T y p e$ text or a website address or ptranslate a document. ada 16 September 1963 di Padang Bandaran, Jesselton. ${ }^{145}$

Pengisytiharan Malaysia dirasmikan oleh Timbalan Perdana Menteri Tun Abdul Razak dan dibacakan oleh Datu Mustapha Datu Harun dan seterusnya mengangkat sumpah sebagai Yang di-Pertua Negara dan Donald Stephens sebagai Ketua Menteri. ${ }^{146}$ Ahli-ahli kabinet negeri yang lain juga dilantik iaitu Khoo Siak Chiew (Menteri Komunikasi dan Kerja), Harris Mohd Salleh (Menteri Kerajaan Tempatan), G.S.Sundang (Menteri Kesihatan), Pang Tet Tsung (Menteri Kebajikan Sosial), Mohd Said Keruak (Menteri Pertanian dan Perikanan) dan Richard Yapp (Menteri Tanah dan Sumber Asli). Pegawai-pegawai British seperti R.N Turner dikekalkan sebagai Setiausaha negeri, W.K.H Jones (Attorney General) dan H.W Davidson (Setiausaha Kewangan). ${ }^{147}$

\section{Kesimpulan}

Donald Stephens dan Datu Mustapha Datu Harun merupakan dua pemimpin penting sebelum dan selepas pembentukan Malaysia. Tidak dinafikan kedua-dua pemimpin ini mempunyai pengaruh kepimpinan tersendiri sehingga dapat mempengaruhi sebahagian besar penduduk Borneo Utara menyertai USNO dan UNKO yang pro-Malaysia. Populariti mereka juga dilihat banyak dibantu oleh pendirian mereka terhadap rancangan Malaysia. Kemenangan Perikatan Sabah dalam pilihan raya Majlis Bandaran dan Kerajaan Tempatan pada 16 Disember 1962 membuktikan penduduk di Borneo Utara ingin merdeka menerusi pembentukan Malaysia.

Donald Stephens, yang menghadapi persaingan pengaruh dalam kalangan masyarakat Kadazan, Dusun dan Murut daripada G.S. Sundang dilihat mendominasi populariti dalam kalangan masyarakat tersebut apatah lagi beliau mempunyai akhbar sendiri bagi menyampaikan pendiriannya. Donald Stephens menggunakan sumber kewangan sendiri untuk menerbitkan akhbar Sabah Times dan North Borneo News sedangkan G.S. Sundang tidak mempunyai akhbar miliknya sendiri.

Perbincangannya dengan Lee Kuan Yew di Singapura dan lawatannya ke Malaya pada bulan Ogos 1961 merupakan titik mula Donald Stephens mengubah pendiriannya terhadap Malaysia. Pembangunan yang beliau dan rakan-rakannya lihat di Kuala Lumpur juga menjadi antara sebab beliau semakin serius untuk merealisasikan penyertaan Sabah dalam pembentukan Malaysia. Dakwaan pembangkang di Semenanjung bahawa prospek Donald Stephens untuk menjadi Ketua Menteri selepas Malaysia juga berkemungkinan menambah tarikannya untuk kekal teguh dengan 
pendiriannya. ${ }^{148}$ Tidak dinafikan ancaman Indonesia dan tuntutan Filipina terhadap Sabah juga menjadi salah satu sebab Donald Stephens kekal menyertai pembentukan Malaysia sungguhpun beliau sedar bahawa Sabah boleh menjadi sebuah negara merdeka selepas diberi kemerdekaan oleh British pada 31 Ogos 1963.

\section{Nota}

1 CO1030/1022(97) Submission by North Borneo to the Commission of Enquiry on Greater Malaysia. Memorandum by Sir William Goode, Governor, North Borneo, 29 April 1962.

2 CO1030/992 (45) Cabinet of Greater Malaysia, Paper by The Colonial Office, Attitude to Greater Malaysia in the Borneo Territories, 25 September 1961.

3 CO1030/1022(97) Submission by North Borneo to the Commission of Enquiry on Greater Malaysia. Memorandum by Sir William Goode, Governor, North Borneo, 29 April 1962.

Ibid.

Ibid.

Ibid.

CO1030/992 (45) Cabinet of Greater Malaysia, Paper by The Colonial Office, Attitude to Greater Malaysia in the Borneo Territories, 25 September 1961.

8 CO1030/1027. Section D: Summary of Evidence from Indigenous and Chinese Population and Political Parties. Report of The Commission of Enquiry, North Borneo and Sarawak, 1962, para 118.

9 Ibid., para 123.

$10 \quad$ Ibid., para 133-137.

$11 \quad$ Ibid., para 131.

12 James Wong Kim Min, The Birth of Malaysia, Malaysia: Sweet and Maxwell Asia, 2008. hlm. 50.

13 Ibid.

14 CO1030/1022(97) Submission by North Borneo to the Commission of Enquiry on Greater Malaysia. Memorandum by Sir William Goode, Governor, North Borneo. 29 April 1962.

15 James Wong Kim Min, The Birth of Malaysia, Malaysia: Sweet and Maxwell Asia, 2008. hlm. 50.

16 DO 169/24 (180) The Future of Borneo Territories, An Address By The Honourable Mr D.A. Stephens in Budget Meeting of The Legislative Council Held at Jesselton on Jesselton on 7th December 1960 on The Subject Closer Association With Sarawak.

17 James P. Ongkili, The Borneo Response To Malaysia 1961-1963, Singapore: Donald Moore Press, 1967. hlm. 28.

18 CO1030/1003(37) Cabinet Committee on Greater Malaysia, Brief for Ministers for Discussion with Tunku Abdul Rahman, Prime Minister Federation of Malaya. Who's who. Leading Personalities in Singapore and the North Borneo. 
19

20

Ibid.

CO1030/1022 (34)Submission by the North Borneo to the Commission of Enquiry, North Borneo, Paper for The Malaysia Commission of Enquiry, 29 March 1961.

FCO141/13005 UNKO, Secretary of Local Government, UNKO di Pedalaman, 29 Ogos 1961.

CO1030/1022 (34)Submission by the North Borneo to the Commission of Enquiry, North Borneo, Paper for The Malaysia Commission of Enquiry, 29 March 1961.

FCO141/13005 UNKO, Secretary of Local Government, UNKO di Pedalaman, 29 Ogos 1961.

FCO 141/13005 Memorandum by Secretary of Local Government, UNKO in the Interior, 29 Ogos 1961 dan CO1030/1023 (1) Extract from North Borneo Sav., 9 November 1961, hlm. 28.

CO1030/1003 Cabinet Committee on Greater Malaysia, Brief for Ministers for Discussion with Tunku Abdul Rahman, Prime Minister, Federation of Malaya, William Goode to Secretary of State for the Colonies, 6 Januari 1962.

DO169/331 Discussion on Malaysia at United Nations. Petitions and Counter Petitions on Malaysia to the United Nations from The Borneo Territories., September 1962.

Herman Luping, Sabah's Dilemma: The political History of Sabah (19601994),Kota Kinabalu, 1994.

Colony of North Borneo Annual Report, 1961, hlm.230.

CO1030/1078 (15) Closer Association of The Borneo Terristories, A.H. Poynton to Sir Norman Brook, 30 June 1960.

DO 169/24 (185) The Future of Borneo Territories, 'The Possibility of A Federation of the Borneo Territories, Singapore and the Federation of Malaya.

Ibid.

CO 1030/1078 (94) Record of Meeting On Borneo Territorries. Phoenix Park, Singapore, 23 January 1960.

Ibid.

CO 1030/1078 (53) Closer Association of The Borneo Territories, Note of a Meeting to discuss the Subject of Closer Association of the Borneo Territories, 29 March 1960 held in Sir John Martin's Room. Ibid.

Ibid.

CO1030/1079 (75) Closer Association of Sarawak and North Borneo, Proposed Federation of Malaysia Commission of Enquiry, North Borneo and Sarawak. Closer Association of Sarawak and North Borneo. Mohammad Noordin Sopiee, 'The Advocacy of Malaysia - Before 1961, 'Modern Asian Studies, Vol.7, No 4, 1973, hlm. 729.

Nik Anuar Nik Mahmud, Konfrontasi Malaysia Indonesia, Bangi: Universiti Kebangsaan Malaysia, 2009, hlm. 26. 
DO 169/24 (225) Brief For The Secretary of The State For The Commonwealth Relations For The Visit of Tunku Abdul Rahman, Prime Minister of Federation of Malaya, 14 Oktober 1960. Ibid.

DO 169/24 (195) The Future of Borneo Territories, Federation of Malaya; Constitutional Development of Borneo Territories, 15 December 1960. Ibid.

DO 169/24 (235) Sir William Goode to John Martin 11 August 1960. The Straits Times, 29 Mei 1961.

R.S. Milne \& K.J. Ratnam, Malaysia New States in a New Nation. Political Development of Sarawak and Sabah in Malaysia. Great Britian: Frank Cass and Company Limited, 1974, hlm. 58.

Tunku juga pernah membuat kenyataan untuk mencadangkan agar Sarawak atau sebahagian daripada wilayah Sarawak yang kebanyakannya Melayu dan Dayak dikembalikan semula kepada Brunei. Bagaimanapun Perdana Menteri Britain, Harold Macmillan menyatakan bahawa cadangan ini akan memusnahkan usaha membawa Sarawak menyertai persekutuan Malaysia.(dalam CO1030/1003 Cabinet Committee on Greater Malaysia. Brief for Ministers for Discussion with Tunku Abdul Rahman, Prime Minister Federation of Malaysia, Greater Malaysia: Tunku Abdul Rahman's Proposal, 26 June 1961.)

North Borneo News, 7 Julai 1961.

CO1030/1079 (197) Closer Association for North Borneo and Sarawak, Telegram Lord Selkirk to The Secretary of State for The Colonies, 8 Julai 1961.

Ibid.

James P. Ongkili, The Borneo Response To Malaysia 1961-1963, hlm. 24. CO1030/1079 (197) Telegram William Goode to The Secretary of State for The Colonies, 8 July 1961.

CO1030/1003(37) Cabinet Committee on Greater Malaysia, Brief for Ministers for Discussion with Tunku Abdul Rahman, Prime Minister Federation of Malaya. Who's who. Leading Personalities in Singapore and the North Borneo.

North Borneo News, 7 Julai 1961.

Ibid.

CO1030/1079 (197) Closer Association for North Borneo and Sarawak, Telegram Lord Selkirk to The Secretary of State for The Colonies, 8 July 1961.

James P. Ongkili, The Borneo Response To Malaysia 1961-1963, hlm. 28. PJ. Granville-Edge dan Rajen Devadson (editor), The Sabahan. The life and Death of Tun Fuad Stephens. Kota Kinabalu: Institute For Development Studies, 1999.

Sunday Times, 23 July 1961.

Tunku Abdul Rahman Putra Al-Haj, Looking Back, Monday Musings and Memories, Selangor: MPH Group Publication Sdn Bhd, 2011.

CO1030/1079 (197) Closer Association for North Borneo and Sarawak, Telegram Lord Selkirk to The Secretary of State for The Colonies, 8 July 1961. 
62 James P. Ongkili, The Borneo Response To Malaysia 1961-1963, hlm. 24.

63 Sarawak Tribune, 11 Julai 1961.

$64 \quad$ North Borneo News, 15 Julai 1963.

65 Straits Times, 10 Julai 1961.

66 The Straits Times, 12 Julai 1961.

67 P.J. Granville-Edge dan Rajen Devadson (editor), The Sabahan. The life and Death of Tun Fuad Stephens, hlm. 116.

Ibid.

69 The Straits Times, 22 Julai 1961.

70 CO 1030/1002 (3) Minutes of The Meeting of The Malaysia Solidarity Consultative Committee held at the Secretariat Conference Room, Jesselton, 24 August 1961.

71 Menurut Tan Sri Ghani Gilong dalam Forum Formation of Malaysia; Sabah's Untold Story, Anjuran Sabah Society Forum,Tanjung Aru, Sabah 11 September 2013.

72 PJ. Granville-Edge dan Rajen Devadson (editor), The Sabahan. The life and Death of Tun Fuad Stephens, hlm 116.

73 North Borneo News, 11 August 1961 dan Buku P.J. Granville-Edge dan Rajen Devadson (editor), The Sabahan. The life and Death of Tun Fuad Stephens, hlm. 116. North Borneo News, 11 Ogos 1961.

FCO141/13005 (33) UNKO. Farewell Speech of the Honorouble Mr. D.A. Stephens addressed to U.N.K.O. members before his departure to the United Kingdom. (disiarkan juga dalam akhbar North Borneo News dan Sabah Times, 13 September 1961.) Ibid. The Straits Times, 16 Ogos 1961.

North Borneo News 18 September 1961, Sabah Times, 18 September 1961. FCO141/13005 (33) UNKO. Farewell Speech of the Honorouble Mr. D.A. Stephens addressed to U.N.K.O. members before his departure to the United Kingdom. (disiarkan juga dalam akhbar North Borneo News dan Sabah Times, 13 September 1961.) Ibid.

81 Ibid.

82 CO1030/1002 (3) The Greater Malaysia: Malaysia Solidarity Consultative Committee, Minutes of The Meeting of the Malaysia Solidarity Consultative Committee, Jesselton, 24 August 1961.

CO1030/1002 (200) The Greater Malaysia: Malaysia Solidarity Consultative Committee, Record of The Meeting of the MSCC Selangor State Legislative Assembly Chamber, 6-7 January 1962. FCO141/13005 (35) UNKO. Secretary of Local Government, UNKO in The Interior, 29 August 1961.

85 FCO141/13005 (33) UNKO. Farewell Speech of the Honorouble Mr. D.A. Stephens addressed to U.N.K.O. members before his departure to the United Kingdom. (disiarkan juga dalam akhbar North Borneo News dan Sabah Times, 13 September 1961.) 
Herman J. Luping, The Kadazan dan Sabah Politics, (Thesis Ph.D), Political Science Department at the Victoria University of Wellington, Wellington, New Zealand, 21 Jun 1985, hlm. 52. Sabah Times, 8 December 1961.

88 Ibid.

89 CO1030/1027. Report of The Commission of Enquiry, North Borneo and Sarawak, 1962, para 125 - 126.

$90 \quad$ C1030/1023 (28) United National Pasok Momogun Organisation.

$91 \quad$ FCO141/13005 (35) United National Kadazan Organisation.

92 P.J. Granville-Edge, Rajen Devadason (Editor), The Sabahan, The Life and Death of Tun Fuad Stephens, Selangor: Family of the Late of Tun Fuad Stephens, 1999, hlm. 29 - 37.

93 Bagaimanapun terdapat pandangan pegawai-pegawai British bahawa Donald Stephens dan Datu Mustapha tidak semestinya dianggap mewakili Borneo Utara sungguhpun tiada pilihanraya di Borneo Utara pada masa itu. (dalam CO1030/1003(37) Cabinet Committee on Greater Malaysia, Brief for Ministers for Discussion with Tunku Abdul Rahman, Prime Minister Federation of Malaya. Who's who. Leading Personalities in Singapore and the North Borneo.) FCO141/13005 (46) United National Kadazan Organisation. 7 August 1962. CO1030/1031 (126) From the Governor of North Borneo to The Secretary of States for the Colonies, 14 September 1962. Mesyuarat IGC merupakan satu mesyuarat untuk menyediakan cadangan penyusunan perlembagaan yang terperinci untuk Malaysia (dalam CO1030/1031 (64) W.I.J. Wallace to Colonial Office, London, 14 September 1962.) CO1030/1031(126) From the Governor of North Borneo to The Secretary of States for the Colonies, 14 September 1962. Ibid.

100 CO1030/1031 (64) W.I.J. Wallace to Colonial Office, London, 14 September 1962.

101 Ibid.

102 Ibid

103 Pada masa itu, G.S. Sundang baru kembali daripada melawat Kuching dan telah bersetuju untuk berkerjasama dengan Sarawak United Peoples Party (SUPP) dan A.M. Azahari dari Partai Rakyat Brunei yang merancang untuk membuat rayuan di Pertubuhan Bangsa-Bangsa Bersatu (PBB). ( Dalam CO1030/1031 (64) W.I.J. Wallace to Colonial Office, London, 14 September 1962.)

104 CO1030/1031 (92) Telegram Sir William Goode to The Secretary of State for The Colonies, 23 October 1962.

105 DO169/331 Discussion on Malaysia at United Nations. Petitions and Counter Petitions on Malaysia to the United Nations from The Borneo Territories., September 1962. 
106 Herman Luping, 'The Formation of Malaysia Revisited', dalam Jeffery G. Kitingan dan Maximus J. Ongkili (editor), Sabah 25 Years Later, Kota Kinabalu: Institute For Development Studies, 1989. hlm. 11.

Lord Landsdowne ketika menjawab pertanyaan Donald Stephens, menyatakan perkara tersebut akan dibincangkan dalam mesyuarat SubCommittee. (CO1030/1031(164) Record of a Preparatory Meeting of The Intergovernmental Committee Held in Council Chamber, 30 August 1962.)

108 CO1030/1031 (69) John Martin to W.I.J. Wallace, 26 October 1962.

109 Herman Luping, The Formation of Malaysia Revisited, hlm. 11.

110 CO1030/1031 (92) Sir William Goode to Secretary State for Colonies, 23 October 1962.

111 Ibid.

112 Stephen Holley, A White Headhunter in Borneo, hlm 107.

113 Sabah Times, 5 Mac 1963.

114 Straits Times, 22 Disember 1962

115 FCO 141/12812 North Borneo: Internal Political, Note Guest Mr. Ellengton Smith on 25 May 1963.

116 Senarai kabinet Sabah selepas pilihanraya Kerajaan Tempatan Donald Stephens akan menjadi Ketua Menteri, Khoo Siak Chiew (Komunikasi dan Kerja), Pang Tet Tshung (Kebajikan Sosial), G.S. Sundang (Kesihatan), Harris Mohd Salleh (Kerajaan Tempatan), Richard E. Yapp (Sumber Asli, Tanah dan Hutan) dan Said Keruak (Pertanian, Perikanan dan Koperasi) dalam FCO 141/12812 North Borneo: Internal Political. FCO 141/12812 North Borneo: Internal Political, Henry to John Martin, 9 May 1963.

118 FCO 141/12812 Henry to John Martin, 9 May 1963.

119 CO1030/1031(157) Record of Conversation Between the Prime Minister of the Federation of Malaya and the Minister of State for the Colonial Affairs in Kuala Lumpur $1^{\text {st }}$ September 1962. FCO 141/12812 Henry to John Martin, 9 Mei 1963.

121 FCO 141/12812 Draft Brief for the High Commissioner North Borneo Political.

122 James Wong Kim Min, The Birth of Malaysia, Malaysia: Sweet and Maxwell Asia, 2008, hlm.50.

123 FCO 141/12812 Note guest Mr Ellengton Smith on 25 May 1963.

124 DO169/331, North Borneo Information Office to The Secretary of State for The Colonies 13 March 1963.

125 Ibid.

126 Ibid.

127 Ibid.

128 CO1030/1035 (207) Telegram South East Asia Department to Manila, 1 August 1962

129 Stephen Holley, A White Headhunter in Borneo, Kota Kinabalu: Natural History Publications (Borneo), 2004, hlm. 113.

130 Peter Boyce, Malaysia and Singapore in International Diplomacy, Sydney: Sydney University Press, 1968, hlm. 70. 
131 Sabah Times, 27 Ogos 1963.

132 Ibid.

133 Sabah Times, 12 Ogos 1963.

134 Ho Ah Choon, The Formation of Federation of Malaysia, hlm. 230.

135 Ibid., hlm. 228.

136 North Borneo News,17 Ogos 1963.

137 A.G. Mezerik (editor), Malaysia-Indonesia Conflict, New York: International Review Service, Inc, 1965.

$138 \quad$ North Borneo News,1 September 1963.

139 Herman Luping, Sabah Dilemma. The Political History of Sabah 1963 - 1994, hlm. 179.

140 Richard A. Lind, My Sabah Reminiscences of a Former State Secretary, Kota Kinabalu: Natural History Publication (Borneo), 2003. hlm 34.

141 The Borneo Times, 31 Ogos 1963.

142 James Wong Kim Min, The Birth of Malaysia, Agreement Amending The Agreement of $9^{\text {th }}$ July Between The United Kingdom of Great Britain and Northern Ireland, The Federation of Malaya, North Borneo, Sarawak and Singapore Relating To Malaysia, Malaysia: Sweet and Maxwell Asia, 2008. The Malayan Times, 3 September 1963.

144 James Chin,'Pertandingan Tak Setanding: Hubungan Persekutuan-Negeri di Bawah Mahathir.' dalam Hoi Khai Leong dan James Chin (editor) Pentadbiran Mahathir. Prestasi dan Krisis dalam Pemerintahan, Shah Alam: Selangor, 2003, hlm. 35. Richard A. Lind, Reminiscences of a Former State Secretary, Kota Kinabalu: Natural History Publications (Borneo), 2003, hlm. 34.

146 Ibid.

$147 \quad$ Ibid., hlm. 35.

148 DO169/331, Lawrence H.C. Huang, Hon. Secretary Conjoined Opposition Group to Secretary General of United Nations, 26 April 1963. 